\title{
LONGITUDINAL GROWTH OF THE RABBIT TIBIA
} AFTER CALLOTASIS

\author{
DUK YONG LEE, CHIN YOUB CHUNG, IN HO CHOI
}

From Seoul National Unicersity Children's Hospital, Seoul, South Korea

\begin{abstract}
We investigated the effect of bone lengthening by callotasis on longitudinal growth of the tibia in rabbits. Ninety-nine five-week-old immature rabbits were divided into five groups according to the percentage of lengthening: group I, $10 \%$; group II, $20 \%$; group III, $30 \%$; group IV, $40 \%$; and group V, sham operation without lengthening. Corticotomy was performed at the proximal metaphysis of the left tibia and the right tibia was used as a control. The lengthening rate was $0.25 \mathrm{~mm}$ twice daily. Radiological, histomorphometric, and immunohistochemical studies were done on animals killed at the time of corticotomy, at the completion of lengthening, and thereafter every two weeks until 12 weeks.
\end{abstract}

Tibial lengthening did not cause retardation of growth when the bone was lengthened by up to $20 \%$. When the bone was lengthened by $\mathbf{3 0} \%$ or more, growth retardation was evident, and persisted until skeletal maturity.

J Bone Joint Surg [Br] 1993; 75-B :898-903.

Receiced 9 February 1993: Accepted 27 April 1993

Since the introduction of gradual distraction techniques by Ilizarov (1989a,b) and De Bastiani et al (1986, 1987), considerable advances have been made in limb lengthening. Complications can occur, however, if the bone is lengthened beyond the safe limit (Paley 1988). Lee et al (1992) and Choi et al (1993) studied the effect of stretching of the soft tissues, particularly the nerves and muscles, and Bell (1992) reported that degenerative changes can result from increased pressure on the articular surfaces during lengthening. The question of increased pressure on the epiphyseal plate has attracted less attention.

The effects of increased pressure on epiphyseal growth were well established by Heuter and Volkmann in 1862 (Arkin and Katz 1956; Trueta and Trias 1961).

D. Y. Lee, MD, Professor and Director

C. Y. Chung, MD, Assistant Professor

I. H. Choi, MD, Associate Professor

Department of Orthopaedic Surgery, Seoul National University Children`s Hospital, 28 Yungun-Dong. Chongro-Ku, Seoul 110-744, South Korea.

Correspondence should be sent to Professor D. Y. Lee.

(C)1993 British Editorial Society of Bone and Joint Surgery $0301-620 \mathrm{X} / 93 / 6657 \$ 2.00$
According to Arkin and Katz (1956) inhibition by pressure applied along the axis of growth is not an 'allor-none' effect; small increases in pressure may slow growth without stopping it altogether. Many authors (Hass 1945: Blount and Clarke 1949: Arkin and Katz 1956; Siffert 1956) have also reported that direct pressure exerted by staples or a wire loop can completely inhibit epiphyseal growth.

There are few studies in the English literature on changes in growth rate after limb lengthening either by conventional methods or by callotasis. Sofield, Blair and Millar (1958) reported that many patients who were operated on using the Abbott device before the age of 12 years showed a greater discrepancy of leg lengths at skeletal maturity than at the conclusion of leg lengthening. Shapiro (1987) investigated growth rates after diaphyseal lengthening by the method of Wagner and reported that in tibiae which had been lengthened by an average $20 \%$, the growth rate decreased from an average preoperative rate of $88 \%$ of normal to an average of $64 \%$ of normal.

We investigated the effect of tibial lengthening by callotasis on enchondral growth in rabbits.

\section{MATERIALS AND METHODS}

We used 99 New Zealand white rabbits, five weeks old and weighing an average of $650 \mathrm{~g}$. The animals were divided into five groups according to the percentage of initial lengthening: group I ( 21$), 10 \%$ lengthening; group II (19), $20 \%$ lengthening; group III ( 20$), 30 \%$ lengthening; group IV (19), $40 \%$ lengthening: and group V (20), sham operation without lengthening. Corticotomy was performed on the left side and the right was used as a control. Operative technique. Under general anaesthesia with $5 \%$ ketamine and $20 \%$ urethane, the left hindleg was shaved and prepared for operation. Using an aseptic technique, four Kirschner wires were inserted into the tibia perpendicular to its long axis, and the cortices of the tibia and fibula were divided at the proximal metaphysis between the middle two transfixing wires. All four wires were then fixed to a dynamic fixator (Lee et al 1992). Distraction was started, at the rate of $0.25 \mathrm{~mm}$ twice daily, from the third postoperative day, except in group V. Prophylactic antibiotics (50 to $100 \mathrm{mg}$ kanamycin) were injected intramuscularly daily for three days. 
At the time of corticotomy, at the completion of lengthening, and every two weeks thereafter until 12 weeks, we carried out radiographic measurements of tibial lengths, histomorphometric measurements of the thickness of the growth plate, and immunohistochemical studies (5-bromo-2'-deoxyuridine (BrdUrd) labelling) to assess the percentage of proliferating chondrocytes in the growth plate. In cases in which there were changes in growth rate, further radiography was done 17 weeks after corticotomy.

Radiography. Scanograms of both tibiae were made before operation and after to serve as a baseline for the measurement of tibial lengths taken from the most proximal part of the intercondylar eminence to the most distal part of the medial malleolus. The percentage of lengthening was calculated by measuring the change in the distance between the two middle wires and the preoperative tibial length. Direct radiographic measurement of the lengthened segment was unreliable due to callus formation at the corticotomy site (Fig. 1). The actual length of the left tibia after completion of lengthening was calculated by subtracting the lengthened distance between the two middle wires from the total tibial length. We calculated the growth ratio and the relative growth ratio at each period as follows:

Growth ratio of the right tibia $\left({ }^{\circ}\right)$

$$
=\frac{\text { right tibial length at each period }}{\text { preoperative right tibial length }} \times 100
$$

Growth ratio of the left tibia $\left({ }^{\circ}\right)$

$$
=\frac{\text { actual length of the left tibia at each period }}{\text { preoperative left tibial length }} \times 100
$$

Relative growth ratio of the left to right tibia at each period $\left({ }^{\circ}{ }_{0}\right)$

$$
=\frac{\text { actual length of the left tibia }}{\text { right tibial length }} \times 100
$$

Histomorphometry and immunohistochemistry. After removal of the external fixator and wires, both tibiae were removed from each rabbit. The proximal and distal portions of the tibia were taken $3 \mathrm{~cm}$ from the proximal and distal articular surfaces. They were fixed in Carnoy solution for more than 48 hours and decalcified in 5\% nitric acid for two days. Each specimen was bisected in the coronal plane and one half was used for histomorphometric and the other for immunohistochemical studies.

After staining the specimen with haematoxylin and eosin, the total thickness of the proximal and distal growth plates and the thicknesses of their proliferative and hypertrophic zones were measured using a calibrated microscope. The thicknesses at the middle thirds of both medial and lateral halves of the growth plate in section were measured six times and averaged. At this site the variations in the width were minimal and the cell columns

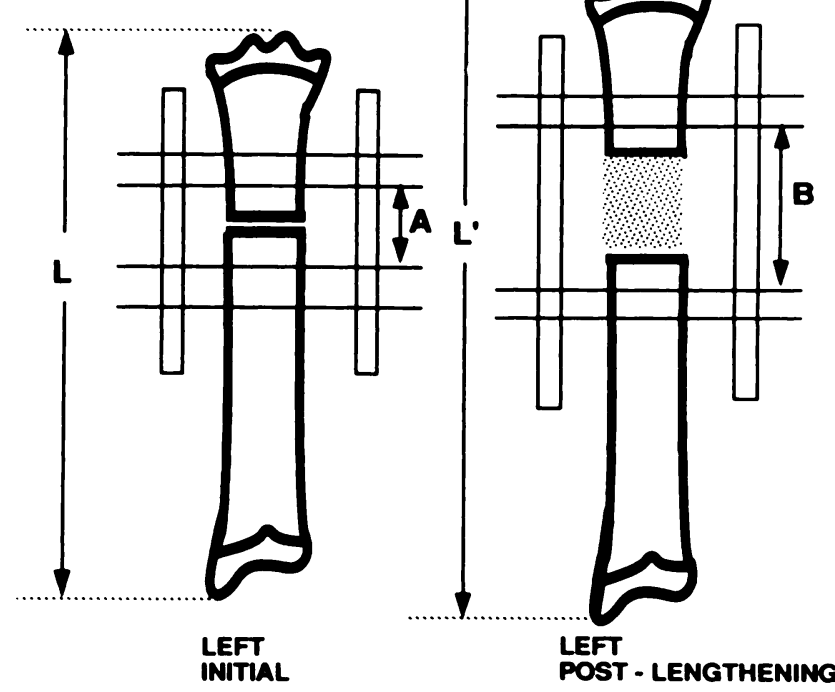

Fig. I

Method of calculating the percentage lengthening.

Percentage lengthening $=\frac{B-A}{L} \times 100$ where $A=$ distance

between the middle two Kirschner wires before lengthening: $\mathrm{B}=$ distance between the middle two Kirschner wires after lengthening: $L$ $=$ length of tibia before lengthening; and $L^{\prime}=$ length of tibia after lengthening.

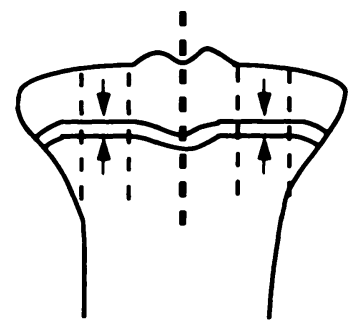

A

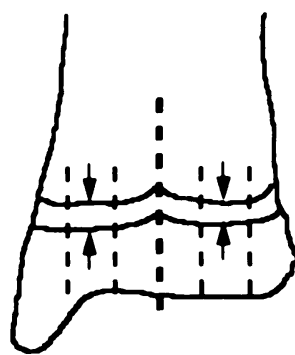

B
Fig. 2

The thicknesses were measured in sections of the middle thirds of the medial and lateral halves of the proximal (A) and distal (B) growth plates. At these sites variation in width was least and the cell columns were orientated perpendicular to the growth plate.

were orientated perpendicular to the growth plate (Fig. 2). The vertical height of the growth plate was measured from the edge of the reserve zone, on to which the secondary epiphyseal ossification centre abutted, to the last hypertrophic chondrocyte in the transverse cartilage septum before vessel ingrowth. The width of the proliferative zone was determined by measuring from the point of origin of the cell columns to the point at which the chondrocytes started to enlarge in size. This junction between the proliferative and hypertrophic zones was judged to be that point at which the cell lacunae were no wider than their vertical height and were becoming rounded. At each time period, we 
calculated the ratios of the left to right thickness of the growth plate as follows:

Ratio of the left to right thickness $(\%)$

$$
=\frac{\text { thickness of the left growth plate }}{\text { thickness of the right growth plate }} \times 100
$$

For the immunohistochemical study, three rabbits in each group had intraperitoneal injections of $25 \mathrm{mg}$ of BrdUrd/kg body-weight, two hours before death at each period. Because it is known that there are diurnal variations in the rate of chondrocyte proliferation (Stevenson et al 1990), all sampling was performed at 10 am. BrdUrd is incorporated into the DNA of proliferating chondrocytes in the growth plate. In sections cut $10 \mu$ thick, incorporated BrdUrd was detected using a monoclonal antibody to BrdUrd. The percentage of labelling was calculated as labelled cells/total number of the chondrocytes within the proliferative zone. At the same sites at which the histomorphometric study was done, ten columns were counted at $\times 400$ magnification and their average labelled percentages were recorded. At each period, the ratio of the left to right BrdUrd labelled cells of the growth plate was calculated as follows:

Ratio of the left to right labelled percentage $(\%)$

$$
=\frac{\text { labelled percentage of the left proliferating chondrocytes }}{\text { labelled percentage of the right proliferating chondrocytes }} \times 100
$$

Statistical analysis. Analysis of the difference between the left and right data was by the Wilcoxon signed-rank test, of the sequential changes in each group by the oneway ANOVA test and Duncan's multiple-range test, and of the differences between the groups by the two-way ANOVA test and Duncan's multiple-range test.

\section{RESULTS}

Radiography. Changes in the growth ratios and in the relative growth ratios of the tibiae in relation to the percentage of lengthening are given in Table $I$. In groups I, II and V, there were no statistically significant differences between the left and right tibiae ( $p>0.05$ ), and the relative growth ratios of the left to right tibiae did not change throughout the periods studied $(p>0.05)$. There were significant differences in the growth ratio between the left and right tibiae in groups III and IV $(p<0.001)$. The relative growth ratios of the left to right tibiae decreased significantly in group III (average $4.2 \%$ ) and in group IV (average $7.0 \%$ ) at the completion of lengthening (6 weeks in group III, 8 weeks in group IV; $\mathrm{p}<0.0001)$. These values remained decreased until skeletal maturity, 17 weeks after corticotomy $(p<0.001)$. The decreased relative growth ratios persisted throughout the periods studied and there were no significant differences between the periods ( $p>0.05$ ). The average decrease was $4.8 \%$ in group III, and $8.6 \%$ in group IV. The decrease in relative growth ratios was greater in group IV than in group III ( $p<0.001 ;$ Fig. 3 ).

Histomorphometry. The changes in the ratios of the left to right total thickness (Table II) and in the ratios of proliferative to hypertrophic zones, depended on the

Table I. Sequential changes in the growth ratios and the relative growth ratios of left and

\begin{tabular}{|c|c|c|c|c|c|c|}
\hline Weeks & $\begin{array}{l}\text { Growth ratio (\%) } \\
\text { and relative } \\
\text { growth ratio } \\
\text { (\%) }\end{array}$ & Group I & Group II & Group III & Group IV & Group V \\
\hline 2 & $\begin{array}{l}\operatorname{Lt}(\%) \\
\operatorname{Rt}(\%) \\
\operatorname{Lt} / \operatorname{Rt}(\%)\end{array}$ & $\begin{array}{l}105.7 \pm 2.0 \\
105.0 \pm 1.9 \\
100.2 \pm 0.7\end{array}$ & $\begin{array}{l}- \\
- \\
-\end{array}$ & $\begin{array}{l}- \\
- \\
-\end{array}$ & $\begin{array}{l}- \\
- \\
-\end{array}$ & $\begin{array}{l}110.5 \pm 2.9 \\
109.8 \pm 2.9 \\
100.6 \pm 0.6\end{array}$ \\
\hline 4 & $\begin{array}{l}\operatorname{Lt}(\%) \\
\operatorname{Rt}(\%) \\
\operatorname{Lt} / \mathrm{Ri}(\%)\end{array}$ & $\begin{array}{l}111.4 \pm 3.9 \\
110.0 \pm 3.8 \\
100.4 \pm 1.3\end{array}$ & $\begin{array}{l}112.8 \pm 4.5 \\
112.7 \pm 4.7 \\
100.1 \pm 1.2\end{array}$ & $\begin{array}{l}- \\
- \\
-\end{array}$ & $\begin{array}{l}- \\
- \\
-\end{array}$ & $\begin{array}{l}118.8+3.8 \\
117.8 \pm 3.7 \\
100.8 \pm 0.8\end{array}$ \\
\hline 6 & $\begin{array}{l}\operatorname{Lt}(\%) \\
\operatorname{Rt}(\%) \\
\operatorname{Lt} / \operatorname{Rt}(\%)\end{array}$ & $\begin{array}{l}126.8 \pm 4.5 \\
126.8 \pm 4.7 \\
100.0 \pm 0.9\end{array}$ & $\begin{array}{r}122.3 \pm 3.8 \\
122.8 \pm 4.1 \\
99.6 \pm 1.4\end{array}$ & $\begin{array}{r}118.0 \pm 7.5 \\
123.2 \pm 8.0 \\
95.8 \pm 2.0\end{array}$ & $\begin{array}{l}- \\
- \\
-\end{array}$ & $\begin{array}{l}127.7 \pm 4.8 \\
126.5 \pm 4.6 \\
100.9 \pm 0.6\end{array}$ \\
\hline 8 & $\begin{array}{l}\operatorname{Lt}(\%) \\
\operatorname{Rt}(\%) \\
\operatorname{Lt} / \operatorname{Rt}(\%)\end{array}$ & $\begin{array}{l}136.5 \pm 0.7 \\
136.3 \pm 5.1 \\
100.1 \pm 0.7\end{array}$ & $\begin{array}{l}129.2 \pm 5.9 \\
128.9 \pm 5.8 \\
100.3 \pm 1.2\end{array}$ & $\begin{array}{r}122.6 \pm 8.3 \\
129.5 \pm 7.4 \\
94.6 \pm 1.9\end{array}$ & $\begin{array}{c}124.1 \pm 10.7 \\
133.5 \pm 8.0 \\
93.0 \pm 5.9\end{array}$ & $\begin{array}{l}134.6 \pm 6.0 \\
133.6 \pm 5.9 \\
100.8 \pm 0.7\end{array}$ \\
\hline 10 & $\begin{array}{l}\text { Lt }(\%) \\
\operatorname{Rt}(\%) \\
\operatorname{Lt} / \mathrm{Rt}(\%)\end{array}$ & $\begin{array}{l}144.6 \pm 4.1 \\
144.6 \pm 4.2 \\
100.0 \pm 0.1\end{array}$ & $\begin{array}{r}131.8 \pm 6.4 \\
132.3 \pm 6.6 \\
99.6 \pm 0.5\end{array}$ & $\begin{array}{c}131.1 \pm 10.3 \\
140.0 \pm 8.7 \\
95.6 \pm 1.8\end{array}$ & $\begin{array}{c}132.3 \pm 11.7 \\
144.6 \pm 9.2 \\
91.5 \pm 5.0\end{array}$ & $\begin{array}{l}144.9 \pm 5.6 \\
143.4 \pm 4.9 \\
101.0 \pm 0.8\end{array}$ \\
\hline 12 & $\begin{array}{l}\text { Lt }(\%) \\
\operatorname{Rt}(\%) \\
\operatorname{Lt} / \text { Rt }(\%)\end{array}$ & $\begin{array}{r}145.3 \pm 3.5 \\
145.8 \pm 3.0 \\
99.7 \pm 0.5\end{array}$ & $\begin{array}{l}132.7 \pm 1.5 \\
132.7 \pm 1.5 \\
100.0 \pm 0.0\end{array}$ & $\begin{array}{c}134.8 \pm 10.7 \\
142.1 \pm 9.6 \\
94.8 \pm 2.1\end{array}$ & $\begin{array}{c}135.0 \pm 10.9 \\
150.3 \pm 10.9 \\
89.8 \pm 5.5\end{array}$ & $\begin{array}{l}151.4 \pm 7.6 \\
150.9 \pm 7.0 \\
100.3 \pm 0.4\end{array}$ \\
\hline 17 & $\begin{array}{l}\text { Lt }(\%) \\
\operatorname{Rt}(\%) \\
\operatorname{Lt} / \operatorname{Rt}(\%)\end{array}$ & $\begin{array}{l}- \\
-\end{array}$ & $\begin{array}{l}- \\
-\end{array}$ & $\begin{array}{c}151.2 \pm 10.4 \\
157.1 \pm 9.8 \\
96.2 \pm 0.8\end{array}$ & $\begin{array}{r}143.3 \pm 1.7 \\
157.0 \pm 5.9 \\
91.2 \pm 1.7\end{array}$ & $\begin{array}{l}- \\
- \\
-\end{array}$ \\
\hline
\end{tabular}
right tibiae in each group (mean $\mathbf{S D}$ ) related to the percentage of lengthening 


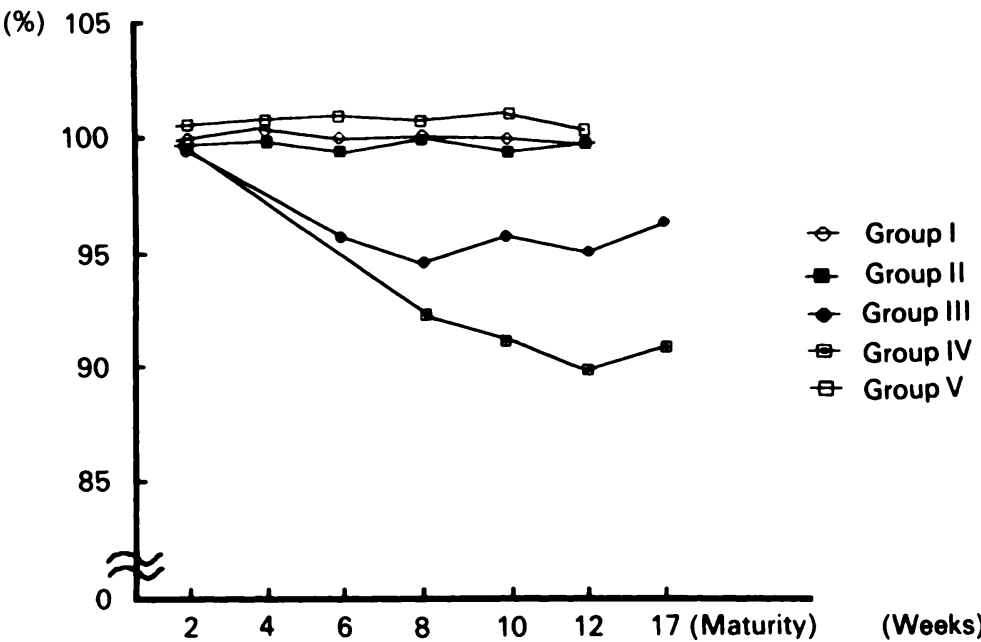

Fig. 3

Graph to show sequential changes in the ratios (mean values) of the left to right tibial lengths in the five groups of animals.

Table II. Sequential changes in the ratios of the total thickness of the growth plate (mean \pm SD) of the left and right tibiae in each group

\begin{tabular}{|c|c|c|c|c|c|c|c|c|c|}
\hline \multirow[b]{2}{*}{ Weeks } & Group I & \multicolumn{2}{|l|}{ Group II } & \multicolumn{2}{|l|}{ Group III } & \multicolumn{2}{|l|}{ Group IV } & \multicolumn{2}{|l|}{ Group V } \\
\hline & Proximal & Proximal & Distal & Proximal & Distal & Proximal & Distal & Proximal & Distal \\
\hline Initial & $\begin{array}{c}99.6 \pm 1.99 \quad 99.8 \pm 1.75 \\
(\mathrm{n}=21)\end{array}$ & \multicolumn{2}{|c|}{$\begin{array}{c}99.6 \pm 1.99 \quad 99.6 \pm 1.75 \\
(n=19)\end{array}$} & \multicolumn{2}{|c|}{$\begin{array}{c}99.6 \pm 1.75 \quad 99.8 \pm 1.75 \\
(n=20)\end{array}$} & \multicolumn{2}{|c|}{$\begin{array}{c}99.6 \pm 1.99 \quad 99.8 \pm 1.75 \\
(n=19)\end{array}$} & \multicolumn{2}{|c|}{$\begin{array}{c}99.6 \pm 1.99 \quad 99.8 \pm 1.75 \\
(n=20)\end{array}$} \\
\hline 2 & $\begin{array}{c}100.3 \pm 1.85 \quad 109.9 \pm 8.12 \\
(\mathrm{n}=21)\end{array}$ & - & - & - & - & - & - & $\begin{array}{r}98.7 \pm 4.15 \\
(n\end{array}$ & $\begin{aligned} & 103.6 \pm 4.12 \\
= & 20)\end{aligned}$ \\
\hline 4 & $\begin{array}{c}99.5 \pm 7.78 \quad 106.2 \pm 9.52 \\
(n=21)\end{array}$ & $\begin{array}{r}96.1 \pm 11.10 \\
(n=\end{array}$ & 9) $95.7 \pm 2.54$ & - & - & - & - & $\begin{array}{r}98.6 \pm 9.63 \\
(n\end{array}$ & $\begin{array}{l}101.3 \pm 7.79 \\
16)\end{array}$ \\
\hline 6 & $\begin{array}{c}99.8 \pm 8.09 \quad 100.1 \pm 4.09 \\
(n=12)\end{array}$ & $\begin{array}{r}99.8 \pm 9.38 \\
(n=\end{array}$ & $99.6 \pm 4.85$ & $\begin{array}{r}86.9 \pm 6.64 \\
(n=\end{array}$ & $\begin{array}{l}82.9 \pm 6.53 \\
=20)\end{array}$ & - & - & $\begin{array}{r}100.1 \pm 11.09 \\
(\mathrm{n}\end{array}$ & $\begin{array}{l}100.6 \pm 3.80 \\
12)\end{array}$ \\
\hline 8 & $\begin{array}{c}97.1 \pm 7.48 \quad 101.3 \pm 5.43 \\
(n=12)\end{array}$ & $\begin{array}{r}101.5 \pm 7.74 \\
(n=\end{array}$ & $99.5 \pm 4.12$ & $89.6 \pm 2.28$ & $\begin{aligned} & 91.2 \pm 7.59 \\
= & 9)\end{aligned}$ & $\begin{array}{r}80.7 \pm 3.11 \\
(n=\end{array}$ & $\begin{aligned} & 89.9 \pm 5.37 \\
= & 19)\end{aligned}$ & $97.8 \pm 3.40$ & $\begin{aligned} & 102.4 \pm 3.64 \\
= & 9)\end{aligned}$ \\
\hline 10 & $\begin{array}{c}101.0 \pm 3.97 \quad 98.2 \pm 7.40 \\
(n=7)\end{array}$ & $\begin{array}{r}101.5 \pm 7.93 \\
(\mathrm{n}\end{array}$ & 8) $100.0 \pm 2.92$ & $\begin{array}{r}92.5 \pm 6.15 \\
(n=\end{array}$ & $\begin{aligned} & 90.5 \pm 5.56 \\
= & 6)\end{aligned}$ & $\begin{array}{r}72.7 \pm 2.64 \\
(n=\end{array}$ & $88.6 \pm 0.31$ & $101.1 \pm 7.35$ & $\begin{array}{l}100.3 \pm 10.63 \\
=6)\end{array}$ \\
\hline 12 & $\begin{array}{c}102.0 \pm 5.45 \quad 99.5 \pm 5.62 \\
(n=3)\end{array}$ & $100.7 \pm 2.68$ & 100.6 & $89.4 \pm 4.41$ & $\begin{aligned} & 87.6 \pm 4.20 \\
= & 3)\end{aligned}$ & $\begin{array}{r}74.7 \pm 5.86 \\
(n\end{array}$ & $\begin{aligned} & 84.2 \pm 3.95 \\
= & 9)\end{aligned}$ & $100.9 \pm 7.71$ & $\begin{aligned} & 100.8 \pm 5.80 \\
= & 3)\end{aligned}$ \\
\hline
\end{tabular}

percentage lengthening. In groups I, II and V, there were no statistically significant differences between these ratios $(\mathrm{p}>0.05)$. In groups III and IV, however, there were significant decreases in the ratios of the total thicknesses of the left to right tibiae at proximal and distal growth plates at the completion of lengthening ( $p<0.0001$ ), and the decreased ratios persisted throughout the study without significant differences between the periods $(\mathrm{p}>0.05)$. The average decrease in the proximal growth plate was $10.4 \%$ in group III and $23.9 \%$ in group IV. In the distal growth plate it was $11.9 \%$ in group III and $12.4 \%$ in group IV. The decrease in the ratios of the total thickness of the growth plate was greater in group IV than in group III in the proximal growth plate $(p<0.001)$, but not in the distal growth plate $(p>0.05)$.

Similar findings were observed in the thickness of the proliferative and hypertrophic zones. The relative thickness of the proliferative zone in the proximal growth plate decreased significantly after lengthening, by an average of $14.7 \%$ in group III and $28.3 \%$ in group IV.
For the distal growth plate, it decreased by an average $19.2 \%$ in group III and $22.3 \%$ in group IV. The ratios of the thickness of the hypertrophic zone also decreased significantly after lengthening, by an average of $13.4 \%$ in group III and $19.4 \%$ in group IV for the proximal growth plate, and by $13.4 \%$ in group III and $14.0 \%$ in group IV for the distal growth plate. The decrease in thickness of the proliferative zone was therefore greater in group IV than in group III in the proximal growth plate $(p<0.001)$, but not so in the distal growth plate $(\mathrm{p}>0.05)$.

Immunohistochemistry. Changes in the ratios of the left to right BrdUrd labelled percentages are given in Table III. In groups I, II and V, there were no significant differences in the ratios of the left to right labelled percentages $(p>0.05)$. In groups III and IV, however, the ratios in both the proximal and the distal growth plates decreased significantly after lengthening $(p<0.0001)$. These decreased ratios persisted throughout the study without significant differences between the 
Table III. Sequential changes in the ratios of the percentage of 5-bromo-2'-deoxyuridine labelling (mean \pm SD) in the left and right tibiae in each group

\begin{tabular}{|c|c|c|c|c|c|c|c|c|c|c|}
\hline \multirow[b]{2}{*}{ Weeks } & \multicolumn{2}{|l|}{ Group I } & \multicolumn{2}{|l|}{ Group II } & \multicolumn{2}{|l|}{ Group III } & \multicolumn{2}{|l|}{ Group IV } & \multicolumn{2}{|l|}{ Group V } \\
\hline & Proximal & Distal & Proximal & Distal & Proximal & Distal & Proximal & Distal & Proximal & Distal \\
\hline Initial & \multicolumn{2}{|c|}{$(n=21)$} & \multicolumn{2}{|c|}{$\begin{array}{c}101.0 \pm 0.21 \\
(n=19)\end{array}$} & \multicolumn{2}{|c|}{$\begin{array}{c}101.0 \pm 0.21 \\
(n=20)\end{array}$} & $\begin{array}{r}101.0 \pm 0.21 \\
(\mathrm{n}=\end{array}$ & 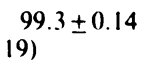 & \multicolumn{2}{|c|}{$\begin{array}{c}101.0 \pm 0.21 \quad 99.3 \pm 0.14 \\
(n=20)\end{array}$} \\
\hline 2 & \multicolumn{2}{|c|}{$\begin{array}{c}98.9 \pm 4.45 \\
(n=21)\end{array}$} & - & & - & - & - & & \multicolumn{2}{|c|}{$\begin{array}{c}106.0 \pm 8.07 \quad 99.0 \pm 5.20 \\
(n=20)\end{array}$} \\
\hline 4 & \multicolumn{2}{|c|}{$(n=21)$} & \multicolumn{2}{|c|}{$(n=19)$} & - & - & - & - & \multicolumn{2}{|c|}{$\begin{array}{c}100.2 \pm 10.79101 .6 \pm 6.49 \\
(n=16)\end{array}$} \\
\hline 6 & \multicolumn{2}{|c|}{$(n=12)$} & \multicolumn{2}{|c|}{$\begin{array}{c}97.5 \pm 5.61 \quad 100.2 \pm 2.21 \\
(n=14)\end{array}$} & \multicolumn{2}{|c|}{$\begin{array}{c}93.4 \pm 11.2289 .6 \pm 9.37 \\
(n=20)\end{array}$} & & & \multicolumn{2}{|c|}{$\begin{array}{c}95.9 \pm 8.07 \quad 116.4 \pm 8.04 \\
(n=12)\end{array}$} \\
\hline 8 & \multicolumn{2}{|c|}{$\begin{array}{l}5.60 \quad 101.3 \pm 6.19 \\
(n=12)\end{array}$} & \multicolumn{2}{|c|}{$\begin{array}{c}99.6 \pm 4.46 \quad 101.2 \pm 2.10 \\
(n=11)\end{array}$} & \multicolumn{2}{|c|}{$\begin{array}{c}90.3 \pm 8.67 \quad 92.1 \pm 3.39 \\
(n=9)\end{array}$} & $\begin{array}{r}80.4 \pm 6.41 \\
(n=\end{array}$ & $\begin{array}{l}80.6 \pm 6.14 \\
19)\end{array}$ & \multicolumn{2}{|c|}{$\begin{array}{c}108.5 \pm 16.97 \quad 109.6 \pm 9.09 \\
(n=9)\end{array}$} \\
\hline 10 & \multicolumn{2}{|c|}{$(n=7)$} & \multicolumn{2}{|c|}{$\begin{array}{c}98.2 \pm 5.55 \\
(n=8)\end{array}$} & \multicolumn{2}{|c|}{$\begin{array}{c}91.1 \pm 7.70 \quad 89.1 \pm 3.50 \\
(n=6)\end{array}$} & $\begin{array}{r}70.0 \pm 13.31 \\
(n=\end{array}$ & $\begin{array}{l}67.5 \pm 6.47 \\
13)\end{array}$ & \multicolumn{2}{|c|}{$\begin{array}{c}99.1 \pm 7.71 \quad 102.5 \pm 7.30 \\
(n=6)\end{array}$} \\
\hline 12 & \multicolumn{2}{|c|}{$(n=3)$} & \multicolumn{2}{|c|}{$(n=3)$} & \multicolumn{2}{|c|}{$(n=3)$} & $77.0 \pm 0.20$ & $80.8 \pm 7.34$ & \multicolumn{2}{|c|}{$(n=3)$} \\
\hline
\end{tabular}
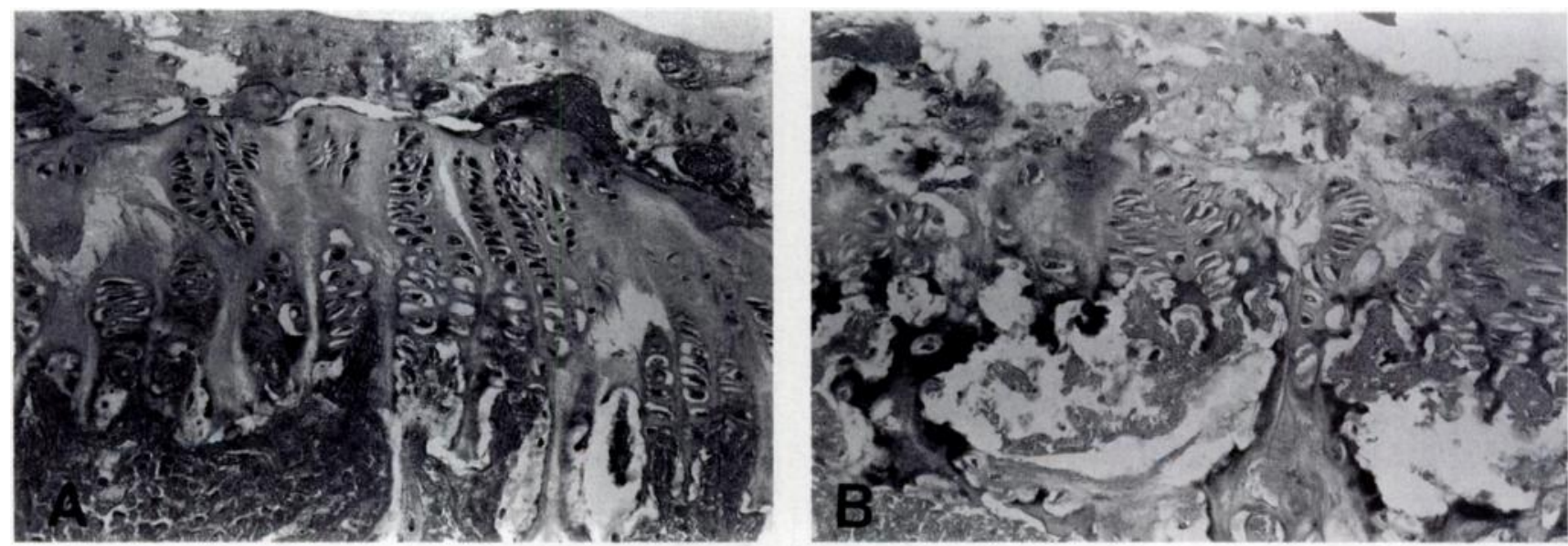

Fig. 4

The growth plate of a lengthened tibia which closed earlier than the control side when the tibia was lengthened $40^{\circ}$ : A. proximal growth plate of the right tibia at 17 weeks; $B$, proximal growth plate of the left tibia at 17 weeks (haematoxylin and eosin $\times 100$ ).

periods ( $p>0.05$ ). Proximally, the ratios of the labelled percentages in groups III and IV decreased by an average of $6.6 \%$ in group III and $19.6 \%$ in group IV. Distally, the decreases were $10.4 \%$ in group III and $19.4 \%$ in group IV. The decrease in the ratios of the labelled percentages at the proximal growth plates 12 weeks after corticotomy averaged $4.0 \%$ in group III and $23.0 \%$ in group IV; distally, it averaged $10.5 \%$ in group III, and $19.2 \%$ in group IV $(\mathrm{p}<0.001)$.

\section{DISCUSSION}

In the widely used method of callotasis for bone lengthening, a distraction rate of $1 \mathrm{~mm} /$ day is usually recommended. Several authors have used modified distraction rates in animal experiments to simulate lengthening in man. In rabbit experiments De Bastiani
(1986) and Yasui et al (1991) used a rate of $0.5 \mathrm{~mm} /$ day in two increments. Shen, Aronson and Badger (1992) reported that a distraction rate of $0.25 \mathrm{~mm}$ twice daily was best for callotasis in the rat. In our rabbit model which simulated callotasis we also used a distraction rate of $0.5 \mathrm{~mm}$ daily in two increments.

There are several methods of estimating the growth rates of long bones: radiological, histomorphometric, radioisotope and immunohistochemical. Seinsheimer and Sledge (1981) reported that the growth rate increased in direct proportion to the thickness of the growth plate, the rate of chondrocyte proliferation, and the ${ }^{35} \mathrm{SO}_{4}$ incorporation associated with matrix synthesis. They found that, of the three variables, the rate of cell division of the proliferative chondrocytes, as determined by the counts of $\left[{ }^{3} \mathrm{H}\right]$ thymidine-labelled cells after autoradiography, was the most sensitive index of the growth rate. 
More recently, Farquharson and Loveridge (1990) noted that the BrdUrd technique allowed accurate determination of cell proliferation and that it had several advantages over $\left[{ }^{3} \mathrm{H}\right]$ thymidine uptake. The method is rapid, problems with non-specific background staining are avoided and it does not require the use of radioisotopes. We used the BrdUrd technique instead of autoradiography to assess the longitudinal growth rate.

In our experiments retardation of enchond al growth did not occur when the bone was lengthened up to $20 \%$, but was evident when lengthening was $30 \%$ or more, and it persisted to skeletal maturity. Growth retardation increased as the bone was lengthened beyond $30 \%$, and the growth plate of the lengthened tibia closed earlier than the control side when the tibia was lengthened $30 \%$ or more (Fig. 4). The histomorphometric studies showed that the decrease in the ratios of all the thicknesses of the growth plate was greater in group IV $(40 \%$ lengthening)

\section{REFFRENCES}

Arkin AM, Katz JF. The effect of pressure on epiphyseal growth. $J$ Bone Joint Surg [Am] 1956: 38-A : 1056-76.

Bell DF. The effect of limb lengthening on articular cartilage: an experimental study. Proc Pediatric Orthopaedic Society of North America, Newport, Rhode Island, 1992:74.

Blount WP, Clarke GR. Control of bone growth by epiphyseal stapling : a preliminary report. J Bone Joint Surg [Am] 1949; 31-A :464-78.

Choi IH, Lee DY, Chung CY, Chung PH, Chi JG. The effect of tibial lengthening on the gastrocnemius muscle in rabbits: a histopathologic and histomorphometric study. Proc Pediatric Orthopaedic Society of North America, White Sulphur Springs, West Virginia, 1993.

De Bastiani G, Aldegheri R, Renzi Brivio L, Trivella G. Limb lengthening by distraction of the epiphyseal plate: a comparision of two techniques in the rabbit. J Bone Joint Surg [Br] 1986; 68-B :545-9.

De Bastiani G, Aldegheri R, Renzi-Brivio L, Trivella G. Limb lengthening by callus distraction (callotasis). J Pediatr Orthop 1987: 7:129-34.

Farquharson $\mathbf{C}$, Loveridge $\mathbf{N}$. Cell proliferation within the growth plate of long bones assessed by bromodeoxyuridine uptake and its relationship to glucose 6-phosphate dehydrogenase activity. Bone Miner 1990; 10:121-30.

Haas SL. Retardation of bone growth by a wire loop. J Bone Joint Surg $1945 ; 27: 25-36$.

Ilizarov GA. The tension-stress effect on the genesis and growth of tissues: part I. The influence of stability of fixation and soft-tissue preservation. Clin Orthop 1989a : 238:249-81.

Ilizarov GA. The tension-stress effect on the genesis and growth of tissues: part II. The influence of the rate and frequency of distraction. Clin Orthop 1989b: $239: 26.3-85$. than in group III ( $30 \%$ lengthening) in the proximal growth plate, but not distally. This difference is probably because the tibia was divided proximally, and because growth at the distal plate is slower than at the proximal one.

We postulate that pressure exerted on the articular surface during bone lengthening compresses the cartilagenous growth plates. The possibility of changes in the dynamics of the blood vessels, however, cannot be ruled out. Nor are we sure that the same phenomenon of growth retardation occurs in man as in our rabbit model when the bones are lengthened beyond $30 \%$. We believe, however, that there must be a safe limit for bone lengthening by callotasis, and that excessive lengthening, in one stage, may cause irreversible damage to the growth plate.

No benefits in any form have been received or will be received from a commercial party related directly or indirectly to the subject of this article.
Lee DY, Han TR, Choi IH, Lee CK, Chung SS. Changes in somatosensory-evoked potentials in limb lengthening: an experimental study on rabbits tibiae. Clin Orthop 1992: $285: 273-9$.

Paley D. Current techniques of limb lengthening. J Pediatr Orthop $1988 ; 8: 73-92$.

Seinsheimer F III, Sledge CB. Parameters of longitudinal growth rate in rabbit epiphyseal growth plates. J Bone Joint Surg [Am] 1981 ; 63A :627-30.

Shapiro F. Longitudinal growth of the femur and tibia after diaphyseal lengthening. J Bone Joint Surg [ Am] 1987: 69-A :684-90.

Shen X, Aronson J, Badger TM. A rat model for the study of limb lengthening. Proc 38th annual meeting Orthopaedic Research Society, 1992:15.

Siffert RS. The effect of staples and longitudinal wires on epiphyseal growth: an experimental study. J Bone Joint Surg (Am] 1956: 38A : $1077-88$

Sofield HA, Blair SJ, Millar EA. Leg lengthening: a personal follow-up of forty patients some twenty years after the operation. $J$ Bone Joint Surg $[\mathrm{Am}]$ 1958: 40-A :311-22.

Stevenson S, Hunziker EB, Herrmann W, Schenk RK. Is longitudinal bone growth influenced hy diurnal variation in the mitotic activity of chondrocytes of the growth plate?.J Orihop Res 1990: 8:1 32-5.

Trueta J, Trias A. The vascular contribution to osteogenesis: IV. The effect of pressure upon the epiphysial cartilage of the rabbit. $J$ Bonc' Joint Surg [ Br] 1961 : 43-B:800-13.

Yasui N, Kojimoto H,Shimizu H,Shimomura Y. The effect of distraction upon bone, muscle, and periosteum. Orthop Clin North Am 1991: 22:56.3-67. 